\title{
PREVALENCE OF WORK-RELATED MUSCULOSKELETAL DISORDERS AMONG PHYSICAL THERAPISTS
}

\author{
CZĘSTOŚĆ WYSTĘPOWANIA ZABURZEŃ UKŁADU MIĘŚNIOWO-SZKIELETOWEGO \\ ZWIAZZANYCH Z PRACA WŚRÓD FIZJOTERAPEUTÓW
}

King Saud University, Riyadh, Saudi Arabia

College of Applied Medical Sciences, Department of Rehabilitation Sciences, Rehabilitation Research Chair

\begin{abstract}
Background: Health professions like dentistry, nursing and physical therapy have been reported at high risk for developing workrelated musculoskeletal disorders. Results of studies conducted in these occupational groups may help formulate prevention strategies. However, no such data among physical therapists has been reported in India. Material and Methods: We conducted an online survey among 100 physiotherapists in Delhi. Results: The response rate was $75 \%$. The prevalence of work-related musculoskeletal disorders is found to be high since $92 \%$ of them reported to feel some pain after joining physical therapy which affects daily activities and even sometimes forces them to change their work. Physical therapists specialty, gender, furniture used in clinic and duration of patient contact are found to be related to the pain development $(p<0.05)$. Conclusions: We need to emphasize the role of ergonomics and techniques of patient handling in development of work-related pain symptoms. Med Pr 2015;66(4):459-469

Key words: risk factors, physical therapists, India, work-related musculoskeletal disorders

STRESZCZENIE

Wstęp: Zawody medyczne, takie jak stomatologia, pielęgniarstwo i fizjoterapia, są zaliczane do grupy wysokiego ryzyka wystąpienia zaburzeń układu mięśniowo-szkieletowego związanych z pracą. Wyniki badań przeprowadzonych w tych grupach zawodowych mogą pomóc w sformułowaniu strategii zapobiegania, jednak nie opracowano ich dla fizjoterapeutów w Indiach. Materiał i metody: Przeprowadzono badanie kwestionariuszowe wśród 100 fizjoterapeutów w Delhi. Wyniki: W badaniu wzięło udział 75\% respondentów. Aż 92\% z nich wskazywało na występowanie zaburzeń układu mięśniowo-szkieletowego związanych z pracą po rozpoczęciu pracy w zawodzie fizykoterapeuty. Wpływają one na codzienne czynności, czasem nawet zmuszając respondentów do zmiany pracy. Specjalność zawodowa fizjoterapeuty, płeć, rodzaj mebli używanych w pracy i czas kontaktu z pacjentem są związane $\mathrm{z}$ rozwojem bólu $(\mathrm{p}<0,05)$. Wnioski: Należy podkreślić rolę ergonomii i technik stosowanych w pracy $\mathrm{z}$ pacjentem w rozwoju dolegliwości bólowych związanych z pracą. Med. Pr. 2015;66(4):459-469
\end{abstract}

Słowa kluczowe: czynniki ryzyka, fizjoterapeuci, Indie, zaburzenia układu mięśniowo-szkieletowego związane z pracą

Corresponding author / Autor do korespondencji: Zaheen Iqbal, King Saud University, College of Applied Medical Sciences, Department of Rehabilitation Sciences, Riyadh 11433, Saudi Arabia, e-mail: z_iqbal001@yahoo.com Received: October 28, 2014, accepted: January 20, 2015

\section{INTRODUCTION}

Work-related disabilities in various professions are very common due to associated musculoskeletal disorders [1]. The physical aspect of work associated with a profession has been reported as the risk factor for developing such work-related musculoskeletal disorders (WRMD) [2,3]. By far, low back pain (LBP) is the most frequently reported WRMD [4]. Health care professions like nursing, dentistry and physical therapy (PT) have been identified at risk for development of the WRMD due to risk factors like heavy physical work; repeated lifting and handling of loads; overstrained and awkward postures in the form of bending; twisting; repetitiveness of different joint movements; use of high frequency vibration tools; psychological stress and prolonged static body position $[2,3,5,6]$.

Several previous studies around the world have reported a high incidence of the LBP among physical therapists (PTs) after joining the profession, ranging 
from $29 \%$ to $68 \%$ in different countries [5,7-9], some of them even claiming that the LBP is among the most prevalent form of the WRMD among them [10]. According to another study, the PTs rank second after nurses with regard to the work-related LBP among all health workers [11] due to the fact that PTs have to repeatedly overload their spines. Most of the patients PTs treat, especially in rehabilitation departments are dependent and cannot move on their own. While treating such patients, they have to frequently lift them or heavy weights and repeatedly bend, stoop, twist, turn or stand for prolonged durations [12-16].

Beside lower back, other joints and muscles are also at risk for development of the WRMDs [5,17], it is however, less reported in literature. Identification and modification of these risk factors is required to prevent their occurrence in such professions in future [18]. This may be achieved if we have data on the prevalence of the WRMD for different professions. To our knowledge, no data on the incidence or prevalence of the WRMD among PTs had been reported in India previously.

The objective of this study has been to report the prevalence of the WRMDs among PT professionals working in New Delhi, India. We also correlate the factors such as age, gender, sub-specialties of PTs and their work environment to their work and nonwork activities of daily living.

\section{MATERIAL AND METHODS}

We used the questionnaire to collect data based on similar studies $[5,13,17]$ published around the world. The questionnaire was first distributed to a few senior local PTs for a pilot study and was adapted for use for PTs working in India. Minor changes were made in the questionnaire in the light of obtained results. The study fully complied with the ethical standards for human research of our University.

\section{Questionnaire}

The questionnaire included 43 questions pertaining to 3 domains, demographic and professional characteristics, general medical history and history of the WRMDs before and after joining the PT profession. These included questions pertaining to work setting characteristics and effect of the WRMD on therapists' daily work and non-work activities. Work-related musculoskeletal disorders were defined as an unpleasant sensation or pain in musculoskeletal system of the body developed after joining the PT profession.
It may or may not affect the ability to perform daily work and non-work activities.

\section{Subjects}

The questionnaire was uploaded online and the web link to the survey along with the explanation of the purpose of the study was sent to the 100 members of the Indian Association of Physiotherapy (IAP) working in Delhi, inviting them to participate in the study. Respondents were assured of confidentiality of their information. After 2 weeks of uploading the questionnaire online, a reminder email was also sent.

\section{Inclusion and exclusion criteria}

The PTs who were members of the IAP and involved in direct patient contact for at least $1 \mathrm{~h}$ per day were eligible to participate. The participants had to complete the questionnaire online. Incomplete questionnaires were not included in the study.

\section{Data analysis}

Data was analyzed using the Statistical Package for Social Sciences (SPSS) software. The Pearson $\mathrm{Chi}^{2}$ test was used to test the correlation between 2 categorical values and Mann-Whiteney test was used to test the difference between 2 quantitative variables. Differences were considered significant if $\mathrm{p}$ value was $\leq 0.05$.

\section{RESULTS}

\section{Demographic data}

Out of 100, 75 (75\%) PTs completed the questionnaire. Among these, 29 (39\%) were females and 46 (61\%) were males. The majority of respondents, $43(57 \%)$ were under the age of 30 years old while 29 (39\%) were between $30-40$ years old (Table 1 ).

\section{Professional characteristics}

Out of 75 respondents, 34 (45\%) were consultant PTs, 26 (35\%) were senior PTs, 14 (19\%) were junior PTs while 13 (17\%) were intern PTs. Among these, 18 (24\%) of the PTs had a Bachelor's degree while 46 (61\%) and 7 (9\%) also had a Master's degree and Ph.D. degrees, respectively. Remaining 4 (5\%) respondents either had a Certificate or a Diploma in PT. Among all, 59 (79\%) respondents indicated that they were satisfied with their current job. Only 7 (9\%) respondents reported to smoke daily.

With regard to the work experience (WE), 29 (39\%) had the WE of more than 5 years, 29 (39\%) had the WE 
Table 1. Basic data and work-related musculoskeletal disorders (WRMD) characteristics of respondents before joining physical therapy profession

Tabela 1. Podstawowe dane i zaburzenia mięśniowo-szkieletowe związane z pracą (WRMD) u respondentów przed rozpoczęciem pracy w zawodzie fizykoterapeuty

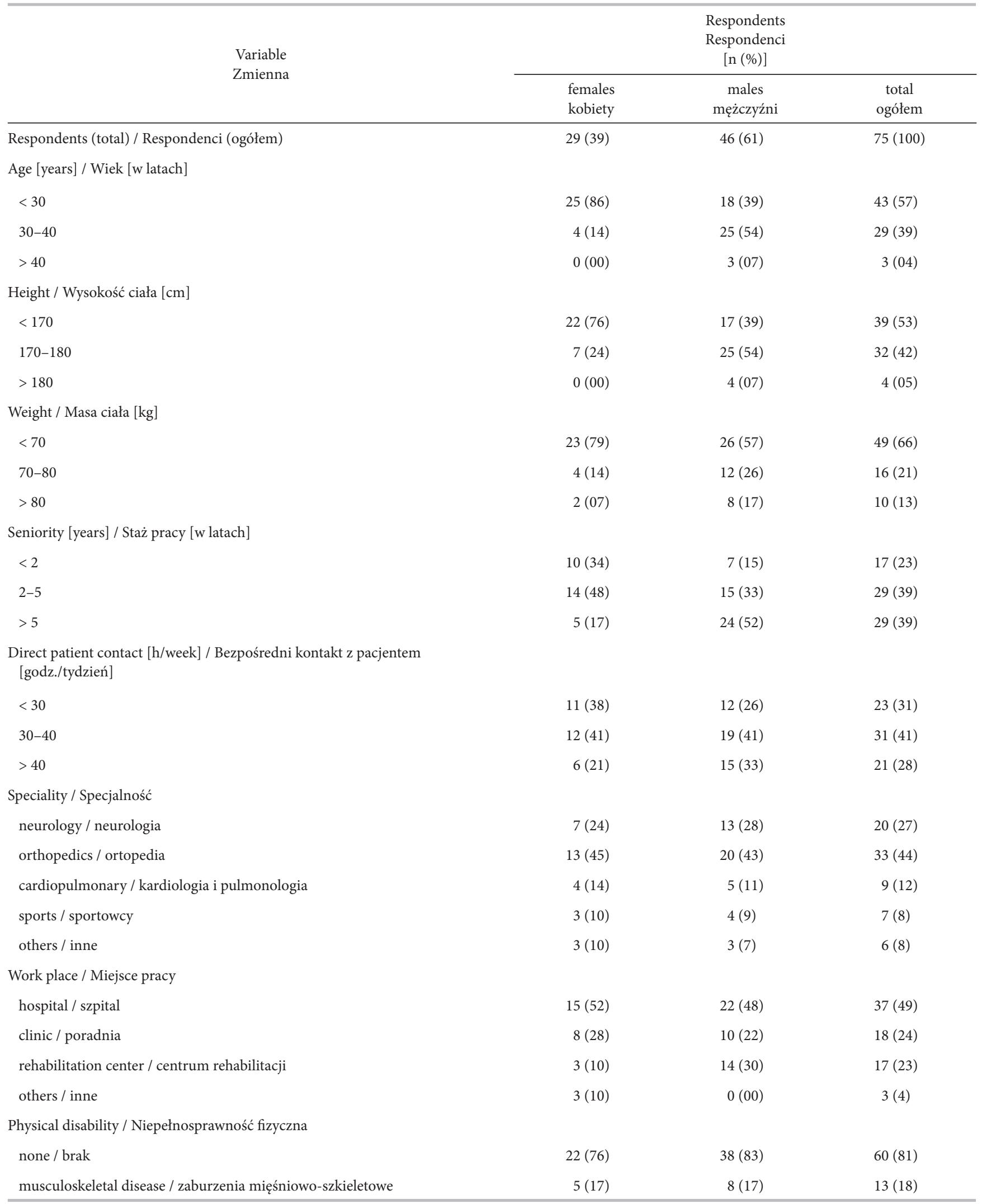


Table 1. Basic data and work-related musculoskeletal disorders (WRMD) characteristics of respondents before joining physical therapy profession - cont.

Tabela 1. Podstawowe dane i zaburzenia mięśniowo-szkieletowe związane z pracą (WRMD) u respondentów przed rozpoczęciem pracy w zawodzie fizykoterapeuty $-\mathrm{cd}$.

\begin{tabular}{|c|c|c|c|}
\hline \multirow{2}{*}{$\begin{array}{l}\text { Variable } \\
\text { Zmienna }\end{array}$} & \multicolumn{3}{|c|}{$\begin{array}{c}\text { Respondents } \\
\text { Respondenci } \\
\text { [n (\%)] }\end{array}$} \\
\hline & $\begin{array}{l}\text { females } \\
\text { kobiety }\end{array}$ & $\begin{array}{l}\text { males } \\
\text { mężczyźni }\end{array}$ & $\begin{array}{l}\text { total } \\
\text { ogółem }\end{array}$ \\
\hline \multicolumn{4}{|c|}{ Physical disability - cont. / Niepełnosprawność fizyczna - cd. } \\
\hline neurological disease / choroby układu nerwowego & $0(0)$ & $0(00)$ & $0(0)$ \\
\hline others / inne & $1(3)$ & $1(2)$ & $2(3)$ \\
\hline \multicolumn{4}{|c|}{$\begin{array}{l}\text { Any musculoskeletal pain before working as a physical therapist / Bóle } \\
\text { mięśniowo-szkieletowe przed rozpoczęciem pracy jako fizjoterapeuta }\end{array}$} \\
\hline yes / tak & $4(17)$ & $6(11)$ & $10(12)$ \\
\hline no / nie & $24(83)$ & $41(89)$ & $65(88)$ \\
\hline \multicolumn{4}{|c|}{$\begin{array}{l}\text { Any functional limitations before working as a physical therapist / } \\
\text { Ograniczenia czynnościowe przed rozpoczęciem pracy jako fizjoterapeuta }\end{array}$} \\
\hline none / brak & $26(90)$ & $44(96)$ & $70(95)$ \\
\hline mild / łagodne & $0(0)$ & $3(4)$ & $3(4)$ \\
\hline moderate / średnie & $1(3)$ & $0(0)$ & $1(1)$ \\
\hline severe / ciężkie & $1(3)$ & $0(0)$ & $1(1)$ \\
\hline
\end{tabular}

between $2-5$ years while 17 (23\%) had the WE of shorter than 2 years. All in all, male respondents were more experienced than female counterparts (Table 1).

\section{Work setting characteristics}

Out of 75 respondents, 15 (20\%) reported to be working in a governmental set up while the remaining 25 (23\%) were working in the private sector. Overall, the main employers were hospitals with 37 (49\%) respondents; private clinics being 2 nd with 18 (24\%) ones and rehabilitation centers - 3rd with 17 (23\%) respondents. Remaining 23 (31\%) were either attached to some university, special school or in community care. Majority of the respondents, 64 (85\%), reported that they had worked as full time therapists with patient contact of more than $3 \mathrm{~h}$ per day.

The most common position adopted during daily work routine was standing with 58 (77\%) respondents while 29 (39\%) reported sitting. Other 19 (25\%) respondents reported walking to be major part of most of daily work routine.

\section{Medical history}

Out of 75 respondents, 69 (95\%) had no other medical condition. Remaining 6 (5\%) reported to suffer either from hypertension, diabetes or cardiac disease. Responding to a question on headache, only 27 (37\%) respond- ents reported that they suffered headache at least 3 times a week but not serious enough to seek its treatment.

\section{History of the WRMD}

\section{before joining the $\mathrm{PT}$ profession}

Out of 75 respondents, 65 (88\%), constituting $24 \mathrm{fe}$ males and 41 males, reported that they had not had any musculoskeletal pain disorder before joining the PT profession. Also, 70 (95\%) respondents, including $26 \mathrm{fe}$ males and 44 males reported that they had no functional limitation or physical disability before working as PTs (Table 1).

\section{Prevalence of the WRMD}

\section{after joining the $\mathrm{PT}$ profession}

Out of 75 respondents, at least 69 (92\%) respondents reported that they had developed some sort of musculoskeletal pain after joining the PT profession (28 females, 41 males). Among these, 20 (30\%) reported that their pain was sudden in origin and at least $22(32 \%)$ respondents reported that they were suffering from work-related pain at the time of the survey (Table 2).

\section{Duration of pain}

Average duration of pain was shorter than 2 weeks in $60(87 \%)$ cases while $9(13 \%)$ reported it to be longer than 2 weeks (Table 2). 
Table 2. Work-related musculoskeletal disorders (WRMD) among responding physical therapists

Tabela 2. Zaburzenia mięśniowo-szkieletowe związane z pracą (WRMD) u badanych fizjoterapeutów

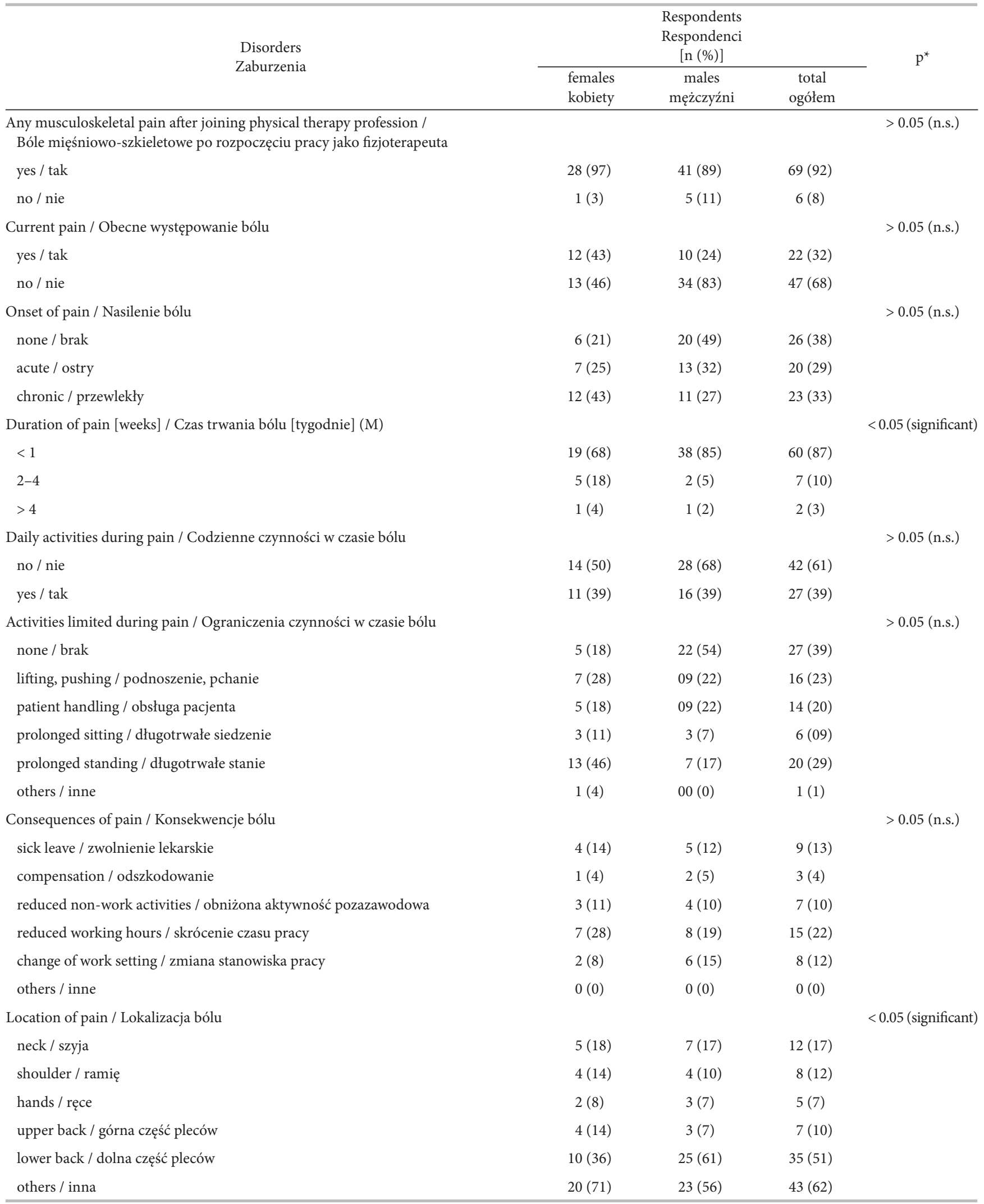

M - mean / średnia, n.s. - statistically not significant / nieistotne statystycznie.

* Pearson $\mathrm{Chi}^{2}$ test / Test $\mathrm{Chi}^{2}$ Pearsona. 


\section{Severity and location of pain}

On the Visual Analog Scale (VAS), 7 (10\%) of the respondents reported their worst ever pain to be less than 3, $30(43 \%)$ - between $3-5$ while $32(46 \%)$ - to be more than 5 . Out of these 32 respondents, 10 (31\%) respondents reported their worst pain 10 in 10.

The distribution of exact location of the LBP is given in the Table 2. Most of the respondents had work-related pain in more than 1 region. Out of 69 respondents reporting to suffer from the WRMD, most of the respondents, 35 (51\%) reported to have pain in the lower back region, 12 (17\%) had pain in the neck region, $8(12 \%)$ - in the shoulder region; $7(10 \%)$ - in the upper back region and 5 (7\%) in hands. At least 43 (62\%) also complained about other regions like elbow, buttocks, thighs, leg, foot, etc.

\section{Daily activities during pain}

Out of 69 respondents who reported to develop the WRMD after joining the PT profession, 27 (39\%) PTs reported that they were unable to practise their daily activities involving bending, stooping, etc. Additionally, 7 (10\%) therapists also reported decreased non-work activities like shopping or home duties to be limited due to pain (Table 2).

\section{Work activities and pain}

Out of 69 respondents who reported to develop the WRMD after joining the PT profession, 49 (71\%) reported that they were unable to practise their daily work activities. The most affected activities due to pain included bending and twisting for 31 (45\%) respondents; prolonged standing for 20 (29\%) respondents; lifting and pushing for 16 (23\%) respondents and prolonged sitting for $6(8 \%)$ respondents. Patient handling/treatment is reported to be the most difficult task by $14(20 \%)$ respondents (Table 2 ).

The severity of pain forced 15 (21\%) PTs to reduce the number of working hours and 17 (25\%) respondents forced to either change their work setting or to go on a sick leave. At least 3 (4\%) of them also reported to claim compensation for their health condition (Table 2).

\section{Self reported risk factors}

Respondents attributed their pain to various different reasons, with 35 (51\%) of them who reported that their WRMD was due to frequent strenuous back position during work, 15 (22\%) - high job demand, 14 (20\%) - repetitive shoulder/hand movements, and 43 (62\%) reported other causes like patient lifting, exertion, low job control, etc.

\section{Treatment for pain}

Out of 69 respondents with the WRMD, 32 (46\%) sought treatment for their pain while remaining 37 (54\%) did not seek any treatment. Physical therapy was sought by at least $15(49 \%)$ respondents while the remaining respondents reported to either consult a physician or take muscle relaxants and analgesics for their pain.

\section{Age and the WRMD}

Out of the total 75 respondents, 72 (96\%) of our respondents were under 40 years of age. Among these, 21 (30\%) reported to be suffering from the WRMD at the time of the survey. As compared to their elder colleagues who had the most complaints in the back and neck, these young respondents complained more about pain in other parts of the body like shoulder, knee, foot and hands. Respondents with the WE of longer than 5 years reported a higher prevalence of the WRMD than those with a shorter WE.

\section{PT specialty and the WRMD}

Out of total 75 respondents, the area of specialty for 33 (44\%) PTs was orthopedics, for 20 (27\%) of them it was neurology and for 7 (9\%) of them it was sports. Remaining 15 (20\%) PTs represented other specialties like cardiopulmonary, geriatrics and pediatrics (Table 1).

Specialty of the therapist is found to be significantly related to the location of the WRMD $(\mathrm{p}<0.05)$. Specialists in orthopedics had major complaints about pain only in the lower back region while specialists in neurology also reported pain in the neck, buttocks and knees along with the lower back region (Table 3).

With 7 (100\%), specialists in sports PT are the most affected with the WRMD, followed by neurology PT with $12(60 \%)$ respondents reporting to suffer. In orthopedics and cardiopulmonary PT, 55\% each reported to develop work-related pain.

\section{Gender and the WRMD}

Duration and location of the WRMD are found to be related to the gender of the therapist $(p<0.05)$. Out of 69 respondents who suffered from the WRMD after joining the PT profession, 28 were females and 41 were males. This accounts for $96 \%$ and $89 \%$ of total female and male respondents. As compared to males, duration of pain in females was longer. The majority of males had most pain complaints in the lower back, neck and 
shoulder region. However, in the case of females along with these regions complaints in the hand and knee region were also reported (Table 2).

\section{Furniture in clinic and the WRMD}

Location of pain among respondents is found to be related to the type of chairs PTs use in their clinical facility $(\mathrm{p}<0.05)$. Prevalence of low back pain is highest among those who use chairs with arm rest, which is the case with 22 (55\%) respondents. Neck and shoulder pain is the highest complaint among those respondents who use chairs without arm rest, which is the case with $3(27 \%)$ complaints each. However, pain in lower limb is higher among those respondents who use fixed chairs that do not revolve (Table 4).

\section{Duration of patient contact and the WRMD}

Out of 75 respondents, 64 (85\%) PTs reported to work as full time therapists ( $>3 \mathrm{~h}$ per day). Among these 23 (31\%) respondents had patient contact of shorter than $30 \mathrm{~h}$ per week, 31 (41\%) had $30-40 \mathrm{~h}$ of patient contact per week while 21 (28\%) had patient contact for more than $40 \mathrm{~h}$ per week (Table 1 ).

Respondents with more patient contact had higher duration of pain $(\mathrm{p}<0.05)$. Among $21 \mathrm{PTs}$ with patient contact of longer than $40 \mathrm{~h}$ per week, $10(50 \%)$ had duration of pain for more than 4 weeks and 5 (25\%) each had average pain duration for shorter than 1 week and 2-4 weeks. Among 31 PTs with patient contact between 30 and $40 \mathrm{~h}$ per week, 10 (33\%) each had duration of pain for more than 4 weeks, shorter than 1 week and 2-4 weeks, respectively. However, among 23 PTs with patient contact of shorter than $30 \mathrm{~h}$ per week, 20 (87\%) PTs had duration of pain for shorter than 1 week while 3 (13\%) for 2-4 weeks. None of the respondents in this case had pain duration for longer than 4 weeks (Table 5).

Table 3. Occupational specialty and location of work-related musculoskeletal disorders (WRMD) among responding physical therapists Tabela 3. Specjalność zawodowa a lokalizacja zaburzeń mięśniowo-szkieletowych związanych z pracą (WRMD) u badanych fizjoterapeutów

\begin{tabular}{|c|c|c|c|c|c|c|c|}
\hline \multirow{2}{*}{$\begin{array}{l}\text { Occupational specialty } \\
\text { Specjalność zawodowa }\end{array}$} & \multicolumn{6}{|c|}{$\begin{array}{c}\text { Pain location } \\
\text { Umiejscowienie bólu } \\
{[\mathrm{n}(\%)]}\end{array}$} & \multirow[b]{2}{*}{$\mathrm{p}^{*}$} \\
\hline & $\begin{array}{c}\text { neck } \\
\text { szyja } \\
(\mathrm{N}=12)\end{array}$ & $\begin{array}{l}\text { shoulder } \\
\text { ramię } \\
(\mathrm{N}=8)\end{array}$ & $\begin{array}{l}\text { hands } \\
\text { ręce } \\
(\mathrm{N}=5)\end{array}$ & $\begin{array}{l}\text { upper back } \\
\text { górna część } \\
\text { pleców } \\
(\mathrm{N}=7)\end{array}$ & $\begin{array}{c}\text { lower back } \\
\text { dolna część } \\
\text { pleców } \\
(\mathrm{N}=35)\end{array}$ & $\begin{array}{l}\text { others } \\
\text { inne } \\
(\mathrm{N}=43)\end{array}$ & \\
\hline Neurology / Neurologia & $4(33)$ & $1(12)$ & $1(20)$ & $1(14)$ & $10(29)$ & $5(12)$ & \multirow{4}{*}{$\begin{array}{c}<0.05 \\
\text { (significant) }\end{array}$} \\
\hline Cardiopulmonary / Kardiologia i pulmonologia & $2(15)$ & $2(25)$ & $0(0)$ & $2(26)$ & $4(11)$ & $4(30)$ & \\
\hline Sports / Sportowcy & $1(8)$ & $0(0)$ & $0(0)$ & $0(0)$ & $4(11)$ & $3(7)$ & \\
\hline Others / Inna & $1(8)$ & $1(13)$ & $0(0)$ & $0(0)$ & $1(3)$ & $0(0)$ & \\
\hline
\end{tabular}

* Pearson $\mathrm{Chi}^{2}$ test / Test Chi ${ }^{2}$ Pearsona.

Table 4. Type of chairs used in clinic vs. location of pain among responding physical therapists

Tabela 4. Rodzaj krzeseł używanych w pracy a lokalizacja bólu u badanych fizjoterapeutów

\begin{tabular}{|c|c|c|c|c|c|}
\hline \multirow{2}{*}{$\begin{array}{c}\text { Pain location } \\
\text { Umiejscowienie bólu }\end{array}$} & \multicolumn{4}{|c|}{$\begin{array}{l}\text { Chair } \\
\text { Krzesło } \\
{[\mathrm{n}(\%)]}\end{array}$} & \multirow{2}{*}{$\mathrm{p}^{*}$} \\
\hline & $\begin{array}{c}\text { fixed } \\
\text { regulowane } \\
(\mathrm{N}=23)\end{array}$ & $\begin{array}{c}\text { revolving } \\
\text { obrotowe } \\
(\mathrm{N}=37)\end{array}$ & $\begin{array}{c}\text { with arm rest } \\
\text { z podłokietnikami } \\
(\mathrm{N}=55)\end{array}$ & $\begin{array}{c}\text { without arm rest } \\
\text { bez podłokietników } \\
(\mathrm{N}=24)\end{array}$ & \\
\hline Neck / Szyja & $3(25)$ & $3(25)$ & $10(83)$ & $3(25)$ & \multirow{6}{*}{$\begin{array}{c}<0.05 \\
\text { (significant }\end{array}$} \\
\hline Shoulder / Ramię & $2(25)$ & $3(37)$ & $3(37)$ & $3(37)$ & \\
\hline Hands / Ręce & $1(20)$ & $4(80)$ & $5(100)$ & $1(20)$ & \\
\hline Upper back / Górna część pleców & $3(43)$ & $4(57)$ & $4(57)$ & $3(44)$ & \\
\hline Lower back / Dolna część pleców & $6(17)$ & $16(46)$ & $22(63)$ & $4(11)$ & \\
\hline Others / Inna & $8(19)$ & $7(16)$ & $11(26)$ & $10(23)$ & \\
\hline
\end{tabular}

* Pearson $\mathrm{Chi}^{2}$ test / Test $\mathrm{Chi}^{2}$ Pearsona. 
Table 5. The frequency of contact with patient vs. average duration of pain among responding physical therapists Tabela 5. Częstość kontaktu z pacjentem a średni czas trwania bólu u badanych fizjoterapeutów

\begin{tabular}{|c|c|c|c|c|}
\hline \multirow{2}{*}{$\begin{array}{c}\text { Direct patient contact } \\
{[\mathrm{h} / \text { week] }} \\
\text { Bezpośredni kontakt z pacjentem } \\
\text { [godz./tydzień] }\end{array}$} & \multicolumn{3}{|c|}{$\begin{array}{l}\text { Respondents with pain } \\
\text { Respondenci z bólem } \\
\text { [n (\%)] }\end{array}$} & \multirow{2}{*}{$\mathrm{p}^{*}$} \\
\hline & $\begin{array}{c}<1 \\
\text { week } \\
\text { tygodnia }\end{array}$ & $\begin{array}{c}2-4 \\
\text { weeks } \\
\text { tygodnie }\end{array}$ & $\begin{array}{c}\quad>4 \\
\text { weeks } \\
\text { tygodnie }\end{array}$ & \\
\hline$<30$ & $17(74)$ & $3(13)$ & $2(9)$ & \multirow{3}{*}{$\begin{array}{c}<0.05 \\
\text { (significant) }\end{array}$} \\
\hline $30-40$ & $25(81)$ & $3(10)$ & $3(10)$ & \\
\hline$>40$ & $19(90)$ & $1(5)$ & $1(5)$ & \\
\hline
\end{tabular}

* Pearson $\mathrm{Chi}^{2}$ test $/$ Test $\mathrm{Chi}^{2}$ Pearsona

\section{DISCUSSION}

The purpose of our study has been to report the prevalence of work-related musculoskeletal disorders among PTs working in Delhi, India. This study was done on a sample of 100 IAP members working in Delhi; however, $75 \%$ of them completed the questionnaire. The prevalence of the WRMD among physical therapists in Delhi India is found to be high with at least 92\% of the respondents reporting to develop some musculoskeletal pain after joining the physical therapy profession. Out of these, $32 \%$ respondents reported that they were suffering from pain at the time of the survey. Our data suggests that the area of PT specialty, gender, furniture used in clinics and duration of patient contact per week are all correlated to this high prevalence. To our knowledge, this is the 1st study of this kind to be done in India.

Our findings are similar to other such studies done in different parts of the world like Kuwait [13], Great Britain [12], Canada, USA [7,14,19], Slovenia [8] and Turkey [9] reporting PT to be a high risk profession for developing work-related musculoskeletal disorders, especially the LBP. In the USA, the highest prevalence of work-related musculoskeletal disorder was in low back, which is the case with $45 \%$ [19]. The life time prevalence of work-related pain was 70\% in Kuwait [13]. In Canada $49 \%$ PTs reported back pain due to work. In our study, along with pain in the lower back region (reported by $51 \%$ respondents), pain in the neck (17\%), shoulder region (12\%), upper back region (10\%) and in hands (7\%) also show high prevalence. It is an irony that PTs who are responsible to treat patients for such pain, suffer from it themselves.

Respondents in our study were relatively young, with $96 \%$ of them under 40 years of age. Among these at least $62 \%$ had work experience of shorter than 5 years (Table 1). High prevalence of work-related pain in these young professionals is either due to overload in the work setting or faulty ergonomics or wrong techniques used during treatment of patients $[12,15]$. Newly qualified PTs do not seem to be using their principles of training or the instructions they give to patients for precautions, into their own practice [16]. Such professionals are at the beginning of their career. As the WRMDs are known to accumulate and increase with age, the problem could grow with time making it difficult for them in future. Strategies are needed to be developed, that should help them to cope with such problems early [14].

Furthermore, in our study specialists in sports seem to be at the most risk of developing the WRMDs, with $100 \%$ of them reporting some or other work-related pain followed by neurology. However, distribution of pain varies in specialists from different areas of PT (Table 3). Such differences in the prevalence of various WRMDs among PTs from different specialties, has been observed in previous studies [20] and may be accounted to the difference in nature of the duties they perform.

Prevalence of the WRMD after joining the PT profession is found to be high in female professionals as compared to their male counterparts. This is accounted for their higher body weight, smaller height and differences in muscle strength and composition [13,19,21,22]. Smaller body builds among females (Table 1) act as a disadvantage when lifting or transferring patients and equipments; and applying body force during treatment, putting extra load on their body, especially spine. Most of the responding female therapists had neurology as their specialty. As compared to orthopedics, neurology patients are more dependent on the therapists and require frequent lifting and transfer. This could be another reason for the high prevalence of the WRMD among female therapists. 
Patients in hospitals are mostly dependent and require more care. This becomes a priority for the therapist, most of the time ignoring their own health. Factors that are identified to increase the risk of the WRMD in PTs are bent or twisted body postures during patient transfers or repositioning and mobilization of joints and soft tissues [14]. In previous studies significant relation has been found between self-reported risk factors and the occurrence of the WRMDs in different parts of the body [20]. Similarly in our study, risk factors reported include frequent strenuous back position during work, repetitive shoulder/hand movements, use of vibrating tools, use of revolving chairs and chairs without armrest, high job demand and others like high exertion and low job control. Height adjustable chairs with arm rest/supports are ergonomically proven to be an efficient intervention to reduce musculoskeletal pain [23,24]. Both physical load and psychological factors play an important role in maintaining general health.

Work-related disorders seem to have a major effect on their daily activities other than work, especially in the case of those with patient contact of longer than $30 \mathrm{~h}$ in a week. Respondents reported significant decrease in activities like shopping, cooking and other home duties. At least 13\% of them reported that they had to go on sick leave, $22 \%$ had to reduce their working hours and $46 \%$ had to seek some treatment for their pain. Other studies also reported sickness absence, changing the work setting and even claiming compensation as the outcome of the WRMDs $[20,25,26]$. Respondents felt unhappy and 'low' after their work time and reported that this was affecting their care towards patients. They should be encouraged to discuss their work load, self-capacity and personal health [14].

Patient handling, transfers and repositioning were not only known to cause pain in PTs $[19,25]$ but also in other health professions like dentistry $[18,27]$ and nursing [28-30]. Preventive measures should always be considered for lifting and handling the patients by incorporating special equipments like suspension frames, sliding boards, sit-to-stand frames, sliding sheets, automatic chairs, sling lifts, other lifting equipment and height adjustable beds. The role of ergonomics; proper techniques of carrying and lifting; manual therapy; healthy work environment; team work; prevention of injury; counseling; etc., need to be emphasized during training of the therapists so that they can use their body force efficiently and effectively without putting extra load on any specific part of the body. Ergonomics may be introduced as a separate course during their studies. Equipments should be encouraged to be used for such purposes.

We need to device the primary as well as secondary prevention strategies to decrease the prevalence of the WRMD among PT professionals so that they can effectively take care and focus on patients. This study needs to be repeated in other parts of India, on a larger sample with a long term follow-up, in order to see how such professionals cope up with such a challenge.

\section{Limitations}

We used a self-report questionnaire to be filled in by the respondents describing their own condition. There are some chances that they may overestimate their past experiences. Non-IAP members were not included in the study. Beside physical factors, the role of psychosocial factors in causing such complains needs to be investigated.

\section{CONCLUSIONS}

The prevalence of work-related musculoskeletal disorders among physical therapist in Delhi, India is high and affects their daily activities, sometimes even forces them to change their work setting. Physical therapist specialty, gender, furniture used in clinic and duration of patient contact are all found to be related to development of pain. Young female therapists with neurology as their specialty are at maximum risk for developing pain. We need to emphasize the role of ergonomics; proper techniques of carrying, lifting, manual therapy, etc., during their training, so that they can work efficiently and effectively.

\section{REFERENCES}

1. Andersson GB. Epidemiological features of chronic lowback pain. Lancet. 1999;354(9178):581-5, http://dx.doi. org/10.1016/S0140-6736(99)01312-4.

2. Szymanska J. Disorders of the musculoskeletal system among dentists from the aspect of ergonomics and prophylaxis. Ann Agric Environ Med. 2002;9(2):169-73.

3. Akesson I, Lundborg G, Horstmann V, Skerfving S. Neuropathy in female dental personnel exposed to high frequency vibrations. J Occup Environ Med. 1995;52(2): 116-23, http://dx.doi.org/10.1136/oem.52.2.116.

4. Omokhodion FO, Sanya AO. Risk factors for low back pain among office workers in Ibadan, Southwest Nigeria. Occup Med (Lond). 2003;53(4):287-9, http://dx.doi. org/10.1093/occmed/kqg063. 
5. West DJ, Gardner D. Occupational injuries of physiotherapists in North and Central Queensland. Aust J Physiother. 2001;47(3):179-86, http://dx.doi.org/10.1016/S00049514(14)60265-8.

6. Coenen P, Kingma I, Boot CR, Twisk JW, Bongers PM, van Dieen JH. Cumulative low back load at work as a risk factor of low back pain: A prospective cohort study. J Occup Rehabil. 2013;23(1):11-8, http://dx.doi.org/10.1007/ s10926-012-9375-z.

7. Molumphy M, Unger B, Jensen GM, Lopopolo RB. Incidence of work-related low back pain in physical therapists. Phys Ther. 1985;65(4):482-6.

8. Rugelj D. Low back pain and other work-related musculoskeletal problems among physiotherapists. Appl Ergon. 2003;34(6):635-9, http://dx.doi.org/10.1016/S00036870(03)00059-0.

9. Salik Y, Ozcan A. Work-related musculoskeletal disorders: A survey of physical therapists in Izmir-Turkey. BMC Musculoskeletal Disord. 2004;5:27, http://dx.doi. org/10.1186/1471-2474-5-27.

10. Cromie JE, Robertson VJ, Best MO. Work-related musculoskeletal disorders and the culture of physical therapy. Phys Ther. 2002;82(5):459-72.

11. Hollingdale R, Warin J. Back pain in nursing and associated factors: A study. Nurs Stand. 1997;11(39):35-8, http://dx.doi.org/10.7748/ns1997.06.11.39.35.c2460.

12. Scholey M, Hair M. Back pain in physiotherapists involved in back care education. Ergonomics. 1989;32(2):179-90, http://dx.doi.org/10.1080/00140138908966078.

13. Shehab D, Al-Jarallah K, Moussa MA, Adham N. Prevalence of low back pain among physical therapists in Kuwait. Medical principles and practice. Int J Kuwait Univ Health Sci Centre. 2003;12(4):224-30.

14. Campo M, Weiser S, Koenig KL, Nordin M. Workrelated musculoskeletal disorders in physical therapists: A prospective cohort study with 1-year follow-up. Phys Ther. 2008;88(5):608-19, http://dx.doi.org/10.2522/ ptj.20070127.

15. Poitras S, Blais R, Swaine B, Rossignol M. Management of work-related low back pain: A population-based survey of physical therapists. Phys Ther. 2005;85(11):1168-81.

16. Glover W, McGregor A, Sullivan C, Hague J. Workrelated musculoskeletal disorders affecting members of the Chartered Society of Physiotherapy. Physiotherapy. 2005;91(3):138-47, http://dx.doi.org/10.1016/j.physio.2005.06.001.

17. Salik Y, Ozcan A. Work-related musculoskeletal disorders: A survey of physical therapists in Izmir-Turkey. BMC Musculoskelet Disord. 2004;5:1-5, http://dx.doi. org/10.1186/1471-2474-5-27.
18. Sharma P, Golchha V. Awareness among Indian dentist regarding the role of physical activity in prevention of work-related musculoskeletal disorders. Indian J Dent Res. 2011;22(3):381-4, http://dx.doi.org/10.4103/0970-92 90.87057.

19. Bork BE, Cook TM, Rosecrance JC, Engelhardt KA, Thomason ME, Wauford IJ, et al. Work-related musculoskeletal disorders among physical therapists. Phys Ther. 1996;76(8):827-35.

20. Alexopoulos EC, Stathi IC, Charizani F. Prevalence of musculoskeletal disorders in dentists. BMC Musculoskelet Disord. 2004;5:16, http://dx.doi.org/10.1186/14712474-5-16.

21. Harutunian K, Gargallo-Albiol J, Figueiredo R, GayEscoda C. Ergonomics and musculoskeletal pain among postgraduate students and faculty members of the School of Dentistry of the University of Barcelona (Spain). A cross-sectional study. Med Oral Patol Oral Ci Bucal. 2011;16(3):e425-9.

22. Miller AE, MacDougall JD, Tarnopolsky MA, Sale DG. Gender differences in strength and muscle fiber characteristics. Eur J Appl Physiol. 1993;66(3):254-62, http:// dx.doi.org/10.1007/BF00235103.

23. Rempel DM, Krause N, Goldberg R, Benner D, Hudes M, Goldner GU. A randomised controlled trial evaluating the effects of two workstation interventions on upper body pain and incident musculoskeletal disorders among computer operators. Occup Environ Med. 2006;63(5):300-6, http://dx.doi.org/10.1136/oem.2005.022285.

24. Carter JB, Banister EW. Musculoskeletal problems in VDT work: A review. Ergonomics. 1994;37(10): 1623-48, http://dx.doi.org/10.1080/00140139408964941.

25. Cromie JE, Robertson VJ, Best MO. Work-related musculoskeletal disorders in physical therapists: Prevalence, severity, risks, and responses. Phys Ther. 2000;80(4):336-51.

26. Cromie JE, Robertson VJ, Best MO. Physical therapists who claimed workers' compensation: A qualitative study. Phys Ther. 2003;83(12):1080-9.

27. Akesson I, Johnsson B, Rylander L, Moritz U, Skerfving S. Musculoskeletal disorders among female dental personnel - clinical examination and a 5-year follow-up study of symptoms. Int Arch Occup Environ Health. 1999; 72(6): 395-403, http://dx.doi.org/10.1007/s004200050391.

28. Retsas A, Pinikahana J. Manual handling activities and injuries among nurses: An Australian hospital study. J Adv Nurs. 2000;31(4):875-83, http://dx.doi.org/10.1046/ j.1365-2648.2000.01362.x.

29. Retsas A, Pinikahana J. Manual handling practices and injuries among ICU nurses. Aust J Adv Nurs. 1999;17(1):37-42. 
30. Alexopoulos EC, Burdorf A, Kalokerinou A. Risk factors for musculoskeletal disorders among nursing personnel in Greek hospitals. Int Arch Occup Environ Health. 2003;76(4):289-94.

This work is available in Open Access model and licensed under a Creative Commons Attribution-NonCommercial 3.0 Unported License / Ten utwór jest dostępny w modelu open access na licencji Creative Commons Uznanie autorstwa - Użycie niekomercyjne 3.0 Unported - https://creativecommons.org/ licenses/by-nc/3.0/deed.en. 